\title{
Balancing Rural Household Livelihood and Regional Ecological Footprint in Water Source Areas of the South-to-North Water Diversion Project
}

\author{
Chen Wang ${ }^{1}$, Guoqing Shi ${ }^{1, *}$, Yongping Wei ${ }^{2}$, Andrew William Western ${ }^{3}$, Hang Zheng ${ }^{2}$ and \\ Yan Zhao ${ }^{2}$ \\ 1 School of Public Administration, Hohai University, Nanjing 211100, China; chenwang@hhu.edu.cn \\ 2 School of Earth and Environmental Science, The University of Queensland, Brisbane 4067, Australia; \\ yongping.wei@uq.edu.au (Y.W.); zhenghang00@163.com (H.Z.); yan.zhao@uq.edu.au (Y.Z.) \\ 3 School of Engineering, The University of Melbourne, Melbourne 3010, Australia; a.western@unimelb.edu.au \\ * Correspondence: gshi1.hhu@gmail.com; Tel.: +86-025-83786503
}

Received: 27 April 2017; Accepted: 3 August 2017; Published: 7 August 2017

\begin{abstract}
There is a knowledge gap and practical demand to understand the co-evolutionary relationship between rural household livelihood and regional ecological footprints for developing sustainable livelihoods in ecological conservation regions. This paper tracks the change trajectories of rural household livelihoods and regional ecological footprints in four water source areas of the South-to-North Water Diversion Project where various ecological and environmental protection projects and measures are being proposed to protect water quality. As a result, some concerns regarding rural livelihood have arisen. The sustainable livelihood approach developed by DFID (Department for International Development in UK) was used to measure the natural, physical, financial, human, and social capitals of rural livelihoods, while the ecological footprint accounting approach was used to calculate the amount of bio-productive spaces that produce the yearly resource flows for human consumption. The study period is 2000-2014 and data was obtained from the Statistical Yearbooks. The results show that the change trend of natural capitals of rural households, which have increased by $72.5 \%$ (SY), 98.8\% (NY), $69.3 \%$ (TA), and $120.3 \%$ (JN) within 15 years, determine the overall change track of rural livelihoods and that rural household livelihood grows with the expansion of regional ecological footprints. Sensitivity of regional eco-footprints to rural livelihood varies from 5.8 to 0.5 in case areas. It is recommended that in the "post South-to-North Water Diversion era", four policy instruments-population transfer and relocation, industrial restructuring and updating, rural infrastructure and community reconstruction, and cross-ecological compensation-should be adopted to improve sustainable livelihoods in these four water source areas.
\end{abstract}

Keywords: livelihood; capitals; rural household; ecological footprint; water source area

\section{Introduction}

Achieving sustainable livelihoods for rural households plays a significant role in the UN's 2030 Agenda on sustainable development, which promotes the livelihood conditions for approximately 700 million people in vulnerable poor areas [1]. Mounting evidence on the factors leading to poor livelihood outcomes at individual, household, and community levels show a large contradiction between the eco-environment endowment and resource demand-dominated livelihood strategies [2-8]. This contradiction stems from either the relatively spatially-fixed nature of limited natural resources or a heavy dependence on the external eco-environment of traditional livelihood activities in rural areas. These two incompatible aspects may further aggravate regional poverty and ecological fragility 
without any external interventions [9-14]. Therefore, much attention should be given to developing more effective tools and approaches for avoiding unsustainable natural resource use as people pursue improved livelihood levels.

The central concept of livelihood is to gain a living. It is built on using the capabilities and assets (stores, resources, claims, and access) in the practical activities under a single or combined strategy [15]. In 1987, the term 'sustainable livelihoods' was used by the World Commission on Environment and Development for the first time to discuss issues on basic needs, resource productivity, ownership security, and rural livelihood. The 1992, the UN Conference on Environment and Development projected sustainable livelihoods as a bridge of linking human behaviors and ecological consequences [16-18]. Since then, increasing concerns have focused on whether livelihood behaviors exert a positive or negative contribution to long-term ecological evolution and whether a tradeoff between human development and ecological security could be realized in a cost-effective way [19]. In response to these concerns, the long-term sustainability of livelihood is emphasized to ensure the maximization of current net benefits and intergenerational equity of utilizing and maintaining the local and regional resources on which livelihoods depend [20-23]. Sustainable Livelihood Approaches (SLA) is widely applied to analyze the linkages and feedbacks between socioeconomic factors and ecological conditions. The most widely-applied SLA was established and advocated by DFID (Department for International Development in the UK). It integrates five major capitals-natural, physical, financial, human, and social—to measure individual, household, and/or community capacity for coping with stress and shocks to livelihoods [24]. The five capitals in this SLA can be accumulated, circulated, substituted, and drawn upon to pursue various livelihood strategies [25-27]. The amount, structure, diversity, and distribution of the five types of livelihood-capitals for rural households determine the efficiency and sustainability of local resource utilization [28]. Additionally, the five types of livelihood-capitals interact closely with changing circumstances, such as the influence of social policies and institutions, and of human activities, such as hydropower constructions, and eco-protection area arrangements [20,29-31].

A multitude of complicated issues that involve the evolution, adaptability, restoration, transition, and diversification of rural household livelihoods have been investigated using empirical-qualitative analysis [32-37]. While these qualitative investigations cannot explicitly trace and depict the ongoing development of rural livelihood and its inner capitals' changes in the contexts of those issues they focused on, recently, livelihood indexation enables the quantitative analysis of livelihood quality, which is served as a decision basis for coping with the vulnerabilities in sustainable development. This approach composites multidimensional factors, such as socio-network, food, and resources with case-based cross-sectional data [38-42]. However, the studies applying the livelihood index to analyze explicit long-term dynamics of the livelihood-ecology nexus are quite limited. Furthermore, the regional level studies are quite limited. Without such knowledge, the capacity of policy-making for long-term sustainable livelihoods would be seriously compromised.

Ecological footprint (EF), a quantitative tool of evaluating the human demand on ecosystems around the globe, represents the total amount of bio-productive spaces required to supply the resources consumed, and to assimilate the waste produced by a well-defined socioeconomic system (including households, cities, provinces, and nations). It is also a measurement to assess sustainability of human development, through observing whether resource consumption has exceeded the Earth's biocapacity to regenerate [43]. EF has been used to reflect both the static and dynamic magnitudes of the human use of ecological resources and services in many studies of sustainable development [44-47]. Combined with many socio-economic factors—such as income, GDP, urbanization, and policy-making-EF could be used to explore the impact of human activities on ecosystems, in a wide socioeconomic context $[48,49]$. Relevant studies suggest that establishing eco-conservation areas for water, biodiversity, and soil, and implementing diverse livelihood projects could be a win-win strategy [31,50-52]. This alleviates the high-intensity resource use and resolves the conflict and opposition of the original inhabitants in protective areas [53]. Yet, few studies have been explicitly conducted on understanding 
the EF of improved livelihood. For an example, only Hao and Zhang (2015) explored the one-year impact of livelihood diversification on the ecosystems in the northern region of China by using the EF model [54]. As a whole, the observations of dynamic interactions between rural livelihood and its EF are still quite limited.

The South-to-North Water Diversion Project (SNWDP), with the total investment of almost 5 trillion Yuan, a total water diversion length of $5599 \mathrm{~km}$, a total water supply area of 1.45 million $\mathrm{km}^{2}$, and a total population being benefited of 4.38 billion-is the largest and most expansive inter-basin water diversion megaproject in the world [55]. This project is being implemented to alleviate the increasing water shortage in Northern China (Huang-Huai-Hai River Basin) and promote regional coordination and sustainable development. It connects the Yangtze, Huai, Yellow, and Hai Rivers with each other through East, Middle, and West Water Diversion Lines. This project started in December 2002. The first phase, consisting of the East and Middle Line of the SNWDP, has been completed and put into use since November 2013 and December 2014, respectively [56]. In the "post South-to-North Water Diversion era", the key challenge for the project management is to ensure high drinking water quality and, to achieve this, some ecological environmental protection projects and measures are being proposed in the project water source areas. These measures could have negative effects on rural livelihoods [57]. Therefore, developing an understanding of the relationship between local livelihoods and their ecological impact (specifically in terms of water quality) is important to help improve the sustainability of the SNWDP. Research to understand this relationship is also a typical case study for avoiding unsustainable natural resource use induced by pursuing improved livelihoods in general.

The aim of this paper is to understand the relationship between rural livelihood development and ecological footprint change in four water source areas of the SNWDP over a period of 15 years. To that end, the livelihood index that represents a comprehensive quality of rural household livelihoods is developed based on the five classical types of livelihood-capitals to observe long-term evolution of rural livelihood and its inner structural change. Then, the yearly ecological footprint of each water source area is calculated to reveal the intensity of resources consumed by rural households and to explore its variation characteristics. This is followed by a correlation analysis between these obtained livelihood indices and ecological footprints in the same time frame of 15 years. Finally, the paper proposes suggestions for both improving rural household livelihoods and limiting expansion of ecological footprints.

\section{Methods}

\subsection{Study Areas}

We chose four administrative regions on the Middle and of the SNWDP-Shiyan (SY), Nanyang (NY), Tai'an (TA), and Jining (JN) — as case study areas (Figure 1). SY and NY are located in Hubei and He'nan Provinces and they cover $23,680 \mathrm{~km}^{2}$ and $26,600 \mathrm{~km}^{2}$, respectively. TA and JN are both situated in Shandong Province and have an area of $7762 \mathrm{~km}^{2}$ and $11,187 \mathrm{~km}^{2}$, respectively. SY is adjacent to the NY and JN borders TA. Danjiangkou Reservoir, a direct water source in the Middle Line Project, is situated in rural areas of both SY and NY. Lake Dongping and Lake Nansi, which are indirect water sources in the East Line Project, are located in rural areas of TA and JN, respectively.

Given that good water quality is essential to the operation of the SNWDP, Danjiangkou Reservoir areas in SY and NY were considered by local authorities as the water source protection zones of the Middle Line Project in 2015. Since then, regional production and livelihood behaviors which are not conducive to water quality protection and ecological conservation (for instance, investment in heavy industries and land reclamation from wetlands), have started to be restricted or completely prohibited [58,59]. Similarly to the Middle Line Project water sources, the catchments of the two lakes in TA and JN since 2009 have been incorporated into Shandong's key ecological protection zones [60]. 


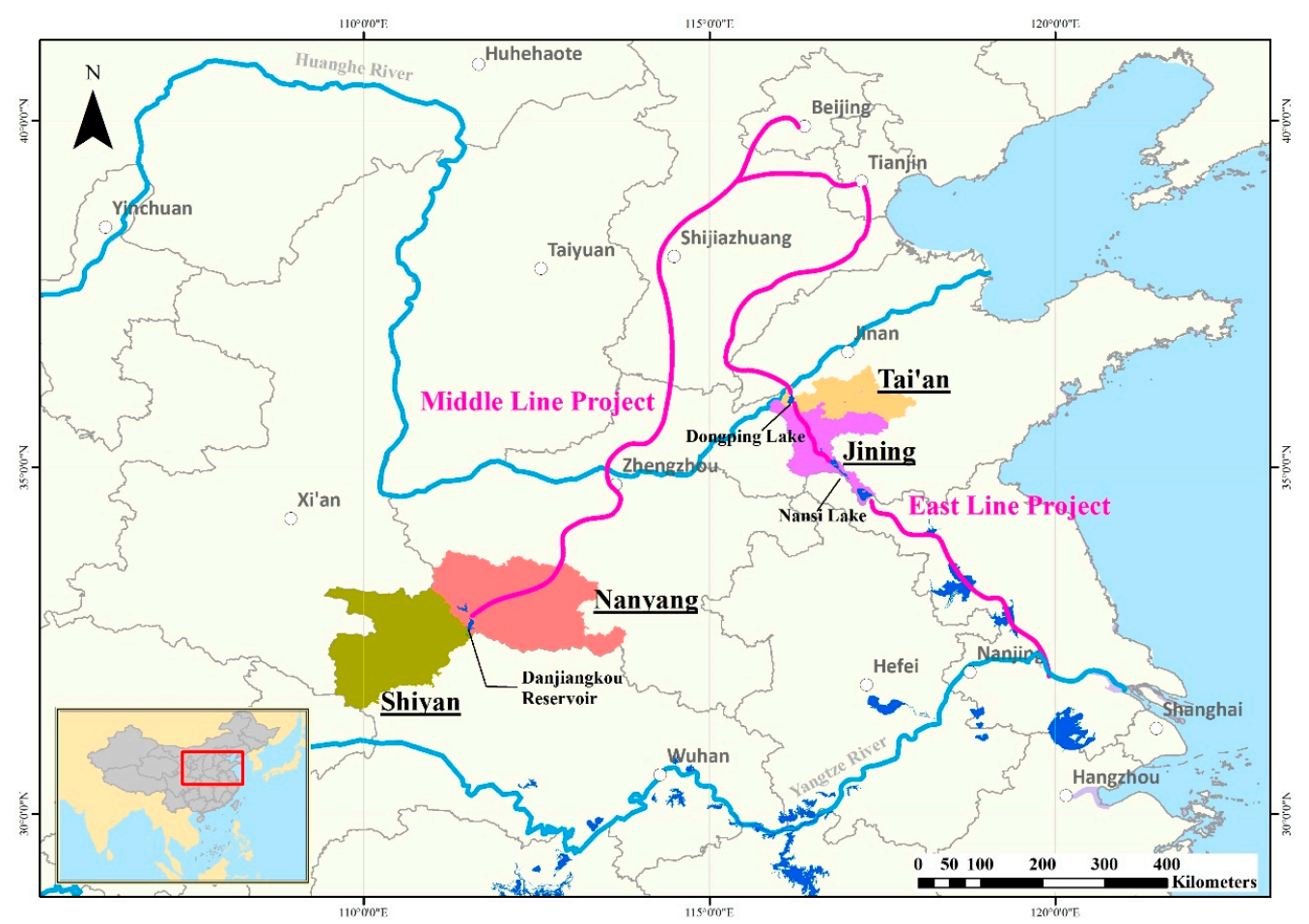

Figure 1. Location and geographic scope of the four water source areas of the South-to-North Water Diversion Project.

\subsection{Research Framework}

A conceptual framework for achieving the aim of this study is developed in Figure 2, which includes research methods and theories used in this study. This framework includes three major research tasks which are introduced below:

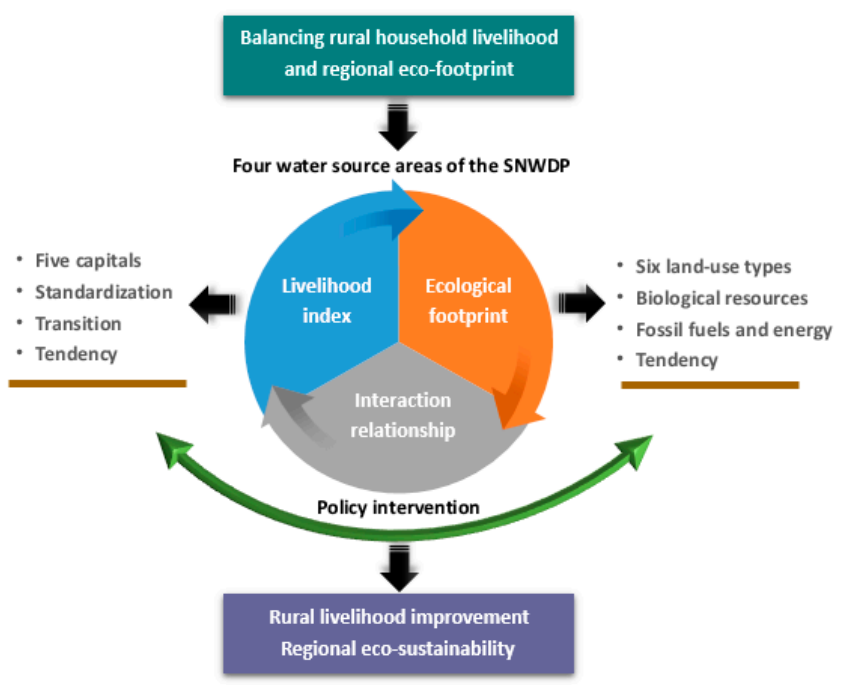

Figure 2. Research framework.

\subsubsection{Selecting the Variables for Analyzing the Change of Rural Livelihood}

Livelihood is a path for rural households to make a living using various types of capitals that are possessed and obtained [10,61]. In this study, we developed a comprehensive livelihood index (LI) by integrating five types of livelihood assets: natural, physical, financial, human, and social capitals 
used in the SLA developed by the DFID [24]. The variables representing each of these five types of livelihood capitals were chosen with reference to relevant theories and studies $[20,24,32,39,40,61,62]$ based on the data availability and data quality, and to avoid correlation between variables $(R>0.8$, $p<0.05)$. The 10 variables used are included in Table 1.

Table 1. Variables selected to represent five types of rural livelihood capitals

\begin{tabular}{|c|c|c|c|c|c|}
\hline Captials & Variables & Unit & $\begin{array}{l}\text { Change } \\
\text { Direction }\end{array}$ & Justification & Initial Data Source \\
\hline \multirow{3}{*}{$\begin{array}{l}\text { Natural } \\
\text { capitals } \\
(\mathrm{NC})\end{array}$} & $\begin{array}{l}\text { Agriculture } \\
\text { land area } \\
\text { (ALA) }\end{array}$ & ha & + & $\begin{array}{l}\text { Land resources are essential for rural } \\
\text { livelihoods; the area size of } \\
\text { agricultural land can reflect the } \\
\text { agricultural land-resource } \\
\text { endowment [41]. }\end{array}$ & $\begin{array}{l}\text { Data were collected from the chapters } \\
\text { of 'Agriculture' in the Shiyan Statistical } \\
\text { Yearbooks, Nanyang Statistical } \\
\text { Yearbooks, Tai'an Statistical Yearbooks, } \\
\text { and Jining Statistical Yearbooks } \\
\text { (2000-2015). }\end{array}$ \\
\hline & $\begin{array}{l}\text { Industrial } \\
\text { waste water } \\
\text { discharge } \\
\text { (IWWD) }\end{array}$ & Ton/year & - & $\begin{array}{l}\text { Industrial waste water discharge } \\
\text { directly reflects the negative impact of } \\
\text { industrial activities on the natural } \\
\text { environment of water source areas; } \\
\text { changes in this variable can be used } \\
\text { to explain the effectiveness of water } \\
\text { protection, and of the implementation } \\
\text { for water quality maintenance policy } \\
\text { of water source areas }[58,59,61] \text {. }\end{array}$ & $\begin{array}{l}\text { The } 15 \text {-year data for this variable in } \\
\text { each study area were collected from the } \\
\text { chapters of 'Industry' or } \\
\text { 'Environmental protection' in the } \\
\text { Shiyan Statistical Yearbooks, Nanyang } \\
\text { Statistical Yearbooks, Tai'an Statistical } \\
\text { Yearbooks, and Jining Statistical } \\
\text { Yearbooks. }\end{array}$ \\
\hline & $\begin{array}{l}\text { Precipitation } \\
\text { (P) }\end{array}$ & $\mathrm{mm} /$ year & Two-way & $\begin{array}{l}\text { Precipitation describes the variation } \\
\text { in general characteristics of climate in } \\
\text { the water source area [63]. }\end{array}$ & $\begin{array}{l}\text { These data were collected from the } \\
\text { chapters of 'Summary' and 'Climate' in } \\
\text { the Statistical Yearbooks (2000-2015) of } \\
\text { these four study areas. }\end{array}$ \\
\hline \multirow{2}{*}{$\begin{array}{l}\text { Physical } \\
\text { capitals } \\
\text { (PC) }\end{array}$} & $\begin{array}{l}\text { Total power of } \\
\text { agricultural } \\
\text { machinery } \\
\text { (TPAM) }\end{array}$ & $\mathrm{kWh} /$ year & + & $\begin{array}{l}\text { Machinery power reflects the overall } \\
\text { quality of agricultural production } \\
\text { machinery [64] }\end{array}$ & $\begin{array}{l}\text { The original data for the TPAM were } \\
\text { gathered from the chapters of } \\
\text { 'Agriculture' in the Shiyan Statistical } \\
\text { Yearbooks, Nanyang Statistical } \\
\text { Yearbooks, Tai'an Statistical Yearbooks, } \\
\text { and Jining Statistical Yearbooks } \\
\text { (2000-2015). }\end{array}$ \\
\hline & $\begin{array}{l}\text { Length of roads } \\
\quad(\mathrm{LR})\end{array}$ & $\mathrm{Km} /$ year & + & $\begin{array}{l}\text { Road length is used to reflect the } \\
\text { connection of rural residents to the } \\
\text { external world [ } 42 \text { ] }\end{array}$ & $\begin{array}{l}\text { These data were gathered from the } \\
\text { chapters of 'Transportation' and } \\
\text { 'Infrastructure' in the Shiyan Statistical } \\
\text { Yearbooks, Nanyang Statistical } \\
\text { Yearbooks, Tai'an Statistical Yearbooks, } \\
\text { and Jining Statistical Yearbooks } \\
\text { (2000-2015). }\end{array}$ \\
\hline \multirow[t]{2}{*}{$\begin{array}{l}\text { Financial } \\
\text { capitals } \\
\text { (FC) }\end{array}$} & $\begin{array}{l}\text { Annual net } \\
\text { income of rural } \\
\text { household } \\
\text { (ANIRH) }\end{array}$ & Yuan/person & + & $\begin{array}{l}\text { Net income includes migrant working } \\
\text { income, household business income, } \\
\text { property income, and transfer income. } \\
\text { This variable represents purchasing } \\
\text { power, and living standards of rural } \\
\text { residents [19]. }\end{array}$ & $\begin{array}{l}\text { These data were collected from the } \\
\text { chapters of 'Rural Household Life' in } \\
\text { the Statistical Yearbooks (2000-2015) of } \\
\text { these four study areas. }\end{array}$ \\
\hline & $\begin{array}{c}\text { Annual value } \\
\text { of rural owned } \\
\text { houses } \\
\text { (AVROH) }\end{array}$ & Yuan/Sq.m & + & $\begin{array}{l}\text { The value of rural housing changes } \\
\text { with the real estate market in the } \\
\text { study areas }[23,27] \text {. }\end{array}$ & $\begin{array}{l}\text { These data were collected from the } \\
\text { chapters of 'Rural Household Life' in } \\
\text { the Statistical Yearbooks (2000-2015) of } \\
\text { these four study areas. }\end{array}$ \\
\hline \multirow{2}{*}{$\begin{array}{l}\text { Human } \\
\text { Capitals } \\
\text { (HC) }\end{array}$} & $\begin{array}{l}\text { Annual } \\
\text { consumption of } \\
\text { food in rural } \\
\text { households(ACFRH) }\end{array}$ & Yuan/person & Two-way & $\begin{array}{l}\text { Food intake reflects the nutritional } \\
\text { level of rural residents }[19,40] \text {. }\end{array}$ & $\begin{array}{l}\text { These data were collected from the } \\
\text { chapters of 'Rural Household Life' in } \\
\text { the Statistical Yearbooks (2000-2015) of } \\
\text { these four study areas. }\end{array}$ \\
\hline & $\begin{array}{l}\text { Number of } \\
\text { vocational } \\
\text { skills schools } \\
\text { (NVSS) }\end{array}$ & Unit/year & + & $\begin{array}{l}\text { This variable expresses the } \\
\text { involvement of rural residents in } \\
\text { vocational skills training and their } \\
\text { education level [63]. }\end{array}$ & $\begin{array}{l}\text { The 15-year original data for the NVSS } \\
\text { were gathered from the chapters of } \\
\text { 'Education' in the Shiyan Statistical } \\
\text { Yearbooks, Nanyang Statistical } \\
\text { Yearbooks, Tai'an Statistical Yearbooks, } \\
\text { and Jining Statistical Yearbooks } \\
\text { (2000-2015). }\end{array}$ \\
\hline $\begin{array}{l}\text { Social } \\
\text { capitals } \\
\text { (SC) }\end{array}$ & $\begin{array}{c}\text { Number of } \\
\text { community } \\
\text { service facilities } \\
\text { (NCSF) }\end{array}$ & Unit/year & + & $\begin{array}{l}\text { This variable reflects the quality of } \\
\text { cultural and medical services } \\
\text { provided in rural areas. It is an } \\
\text { important indicator to explain the } \\
\text { comprehensive capacity of social } \\
\text { governance in rural grassroots [65]. }\end{array}$ & $\begin{array}{l}\text { These data were collected from the } \\
\text { chapters of 'Community' and 'Social } \\
\text { Organizations' in the Statistical } \\
\text { Yearbooks (2000-2015) of these four } \\
\text { study areas. }\end{array}$ \\
\hline
\end{tabular}

These variables were then aggregated into an index, to reflect the holistic level of rural livelihood. To use $m$ indicator variable(s) $v_{1}, v_{2}, v_{3}, v_{4}, \ldots, v_{m}$ to characterize the LI of $n$ region(s) within $t$ 
year(s), a cross-section dataset $\mathrm{V}=\left(v_{i j}\right)_{n * m}$ can be obtained for each year. Therefore, we integrated $t$ cross-section data in chronological order to constitute a global variable set, which can be written as

$$
\mathrm{V}=\left[v_{i j}(t)\right]_{n * m}
$$

wherein $v_{i}(1 \leq i \leq n t, 1 \leq j \leq m)$ is the original value of the $j$ th variable of region $i$ within the $t$ th year.

Since the dimension of the original value of each variable is different, standardization was made to ensure comparability of the data. In addition, the standardization method was improved by multiplying the maximum value of the variable data series by 1.05 and dividing the minimum value by 1.05 [66] to avoid boundary value problems of 0 and 1 . According to the attribute of specific variables, the standardized formula can be written as

$$
\begin{aligned}
\text { Positive variable }: V^{\prime}{ }_{i j} & =\frac{\left(v_{i j}-m i n v_{i j}^{i} / 1.05\right)}{\left(1.05 m a x v_{i j}^{i}-m i n v_{i j}^{i} / 1.05\right)} \\
\text { Negative variable }: V^{\prime}{ }_{i j} & =\frac{\left(1.05 m a x v_{i j}^{i}-v_{i j}\right)}{\left(1.05 m a x v_{i j}^{i}-m i n v_{i j}^{i} / 1.05\right)}
\end{aligned}
$$

For two-way variables: take the arithmetic mean value $\overline{v_{i j}}$ of the $j$ th variable in the observation year as the reasonable value, when $v_{i j}<\overline{v_{i j}}$, the calculation is the same as Equation (2), when $v_{i j}>\overline{v_{i j}}$, the computational formula is

$$
V_{i j}^{\prime}=1-\frac{\left(v_{i j}-\overline{v_{i j}} / 1.05\right)}{\left(1.05 m a x v_{i j}^{i}-\overline{v_{i j}} / 1.05\right)}
$$

In Equations (2)-(4), $v^{\prime}{ }_{i j}$ is the standard value of the $j$ th variable of region $i$ within year $t, 1.05 m a x v_{i j}^{i}$ and $m i n v_{i j}^{i} / 1.05$ represent the adjusted maximum and minimum value respectively of the $j^{\text {th }}$ variable data series of region $i$ within year $t$.

The weight coefficient represents the relative importance of each variable in the process of quantifying livelihood. Due to the complexity and subjective nature of weight determination, normalized values of variables were used directly for the total score (LI) without any weights being allocated. LI of region $i$ within a given research period can be expressed as

$$
\mathrm{LI}_{\mathrm{i}}=\sum_{j=1}^{m} v_{i j}(t)
$$

Livelihood transition (LT) starts when there is an inner change of livelihood capital structure due to possible external impacts. The non-parametric approach detects a specific and significant change point statistically within the mean of a time series [67]. This was used for determining the occurrence of a change point in the process of long-term livelihood evolution.

For a time sequence $v_{i}, i=1,2,3, \ldots, n$, the change point was tested by using the statistic $U_{t . n}$, that verified whether two samples $v_{1}, \ldots, v_{k}$ and $v_{k+1}, \ldots, v_{n}$ were the same shape as LI. This statistic $U_{t . n}$ is given by

$$
U_{t . n}=U_{t-1, n}+V_{t, n}
$$

where

$$
\begin{gathered}
V_{t, n}=\sum_{k=1}^{n} \operatorname{sgn}\left(v_{i}-v_{k}\right), \mathrm{i}>k \\
\operatorname{sgn}\left(v_{i}-v_{k}\right)=\left\{\begin{array}{rr}
1 & v_{i}-v_{k}>0 \\
0 & v_{i}-v_{k}=0 \\
-1 & v_{i}-v_{k}<0
\end{array}\right.
\end{gathered}
$$


The test statistic calculated the number of times that a member of the first sample exceeded a member of the second sample. Its statistic, $K_{t}$, and probabilities used in significance determination are given as

$$
\begin{gathered}
K_{t}=\max _{1<t<n}\left|U_{t}\right| \\
\mathrm{P} \cong 2 \exp \left[\frac{-6 K_{t}^{2}}{n^{3}+n^{2}}\right]
\end{gathered}
$$

this means that a significant 'change point' of livelihood exists when $p<0.05$, and the time series is divided into two intervals at the location of the change point $t$ [9].

\subsubsection{Calculating the Ecological Footprint in the Four Water Source Areas}

Ecological footprint analysis is an accounting tool that enables us to calculate the resource consumption and waste assimilation requirements of a defined socioeconomic system in terms of corresponding productive land area [43]. The whole EF model is used to jointly quantify the annual resource use and the availability of the ecosystem by means of the ecological footprint and biocapacity, respectively [68]. As agricultural land serves as an important natural capital variable, it has been incorporated into the measurement of rural LI in Section 2.2.1 above; at the same time, 'biocapacity' represents the amount of bio-productive land area (including agricultural land available) to provide the ecosystem services. To avoid spurious correlations between LI and EF due to the inclusion of the same variable in each measure in Section 2.2.3, only the ecological footprint account estimation was adopted in this paper to observe the intensity of resources consumed by rural households in each water source area.

Year-by-year per capita EF estimation can be principally classified into the consumption accounts of biological resources, fossil fuels, and energy sources. In this paper, biological resource consumption items-which were converted into land-use types of cropland, grazing-land, forestland, and fishing-ground-include grains, vegetables, oil, meat (lamb, beef, pork), milk, fruits, sugar, livestock, eggs, and aquatic-products (fish, shrimp, shellfish). Items included in fossil fuels and energy consumption were coal-coke, crude-oil and gas, fuel-oil and liquefied-petroleum-gas (LPG), and heat and electricity, which are mainly consumptions covered by carbon uptake and built-up lands. In the estimation process, for the sake of mutual references of various ecologically-productive areas, factors of yield and equivalent weight (equilibrium) were introduced to convert local averages to world average yields and areas of different land-use types into global average bio-productivity areas. The ratios of global average calorific power in per unit area of the fossil fuels and energy consumption were adopted $[68,69]$.

For a given water sources area, the $\mathrm{EF}$ is calculated as

$$
\mathrm{EF}=\sum_{i_{E F}=1}^{z} e f_{i_{E F}}=\sum_{i_{E F}=1}^{z} \frac{I_{i_{E F}}+P_{i_{E F}}-F_{i_{E F}}}{e p_{i_{E F}}} \cdot E Q_{c} \cdot Y Q_{i}
$$

where EF refers to the total ecological footprint per capita (hectares/person/yr); $i_{E F}$ indicates the commodity consumed; $e p_{i_{E F}}$ is the global average production capacity of the $i$ th type of goods consumed or the carbon uptake capacity of the $i_{E F}$ th fossil fuel energy consumed; $P_{i_{E F}}$ is the annual output of the $i_{E F}$ th goods consumed; $I_{i_{E F}}$ and $F_{i_{E F}}$ are the import volume and export volume of the $i_{E F}$ th goods, respectively; $E Q_{c}$ is the equivalence factor, $c$ represents the type of used lands, $c=1,2,3$, $\ldots, 6$; and $Y Q_{i}$ is the scaling factor, $i$ means the kind of consumed fossil fuel energy, $i=1,2,3, \ldots, n$. Due to the lack of statistical data on the import-export volume of a specific good, the calculation for this general model was simplified to use the actual consumption for each commodity to replace the computation for $I_{i_{E F}}, F_{i_{E F}}$, and $P_{i_{E F}}$. 
2.2.3. Investigating the Relationship between the Livelihood Index and Ecological Footprint

After quantifying two sets of independent time series data of LI in Section 2.2.1 and EF in Section 2.2.2, the relationship between them was sought with ordinary least squares (OLS) in SPSS 19.0 (Statistical Product and Service Solutions, IBM SPSS Statistics Inc. Chicago, IL, USA) in order to estimate the impact of rural livelihoods on the ecological footprint (Figure 2). In this paper, a confidence interval of $95 \%$ was used and the null hypothesis is that the parameter is 0 [70].

\subsection{Data Collection}

The study period was set from 2000 to 2014 as SNWDP was launched in 2000 and the East and Middle Line of the SNWDP were commissioned on 15 November 2013 and 12 December 2014, respectively. As described in the Table 1, the data of variables for LI were obtained from the chapters in the Shiyan Statistical Yearbooks, Nanyang Statistical Yearbooks, Tai'an Statistical Yearbooks, and Jining Statistical Yearbooks (2000-2015). The 15-year data of the biological-resource consumptions (mentioned in Section 2.2.2) used for EF calculation were collected from the parts of 'Rural Household Life', 'Agriculture', 'Animal Husbandry', and 'Aquaculture' in the Statistical Yearbooks (2000-2015) of the four study areas, while the data of the fossil fuels and energy consumptions were acquired from the sections of 'Industry' and 'Resources and Environmental Protection' in these same Statistical Yearbooks (2000-2015). A very small portion of missing data on physical capitals in certain years were replaced with data from the relevant Hubei Statistical Yearbooks and Shandong Statistical Yearbooks, respectively. All these data in the Statistical Yearbooks were collected from the villages. They were compiled by the Rural Fixed Investigation Team of the four case areas using the method of the Department of Rural Survey of the National Bureau of Statistics (2010). Overall, these Statistical Yearbooks issued by local authorities are the ideal data sources for the long-time series variables that represent region-specific situations.

Factors of $e p_{i_{E F}}, E Q_{c}$, and $Y Q_{i}$ were adopted from the studies of Hao et al. (2015) [54] and Wackernagel et al. (2005) [71]. These parameters have been widely accepted to calculate EF at multiple scales in China $[47,72,73]$. Specifically, the global average production capacities $\left(e p_{i E F}\right)$ for each kind of biological-resource are: grains: $2.7 \mathrm{t} / \mathrm{ha} / \mathrm{yr}$; vegetables: $18.0 \mathrm{t} / \mathrm{ha} / \mathrm{yr}$; edible-oils: $0.4 \mathrm{t} / \mathrm{ha} / \mathrm{yr}$; meats: $0.033 \mathrm{t} / \mathrm{ha} / \mathrm{yr}$; milk: $0.5 \mathrm{t} / \mathrm{ha} / \mathrm{yr}$; livestock: $0.8 \mathrm{t} / \mathrm{ha} / \mathrm{yr}$; eggs: $0.4 \mathrm{t} / \mathrm{ha} / \mathrm{yr}$; aquatic-products: $0.029 \mathrm{t} / \mathrm{ha} / \mathrm{yr}$; and fruits and sugars: $18.0 \mathrm{t} / \mathrm{ha} / \mathrm{yr}$, respectively. The carbon uptake capacity $\left(e p_{i_{E F}}\right)$ for consumption of coal-coke is $55 \mathrm{GJ} / \mathrm{ha} / \mathrm{yr}$, for crude-oil and gas is $93 \mathrm{GJ} / \mathrm{ha} / \mathrm{yr}$, for fuel-oil and LPG is $71 \mathrm{GJ} / \mathrm{ha} / \mathrm{yr}$, and for heat-electricity is $1000 \mathrm{GJ} / \mathrm{ha} / \mathrm{yr}$. The equivalence factor $\left(E Q_{c}\right)$ for the six kinds of land-use types are 2.8 (cropland), 0.5 (grazing-land), 1.1 (forestland and carbon-uptake land), 0.2 (fishing-ground), and 2.8 (built-up land) respectively. The scaling factors $\left(Y Q_{i}\right)$ for the consumed fossil fuel energy are coal: $20.934 \mathrm{GJ} / \mathrm{t}$; coke: $28.47 \mathrm{GJ} / \mathrm{t}$; crude-oil: $41.868 \mathrm{GJ} / \mathrm{t}$; gas, kerosene, and diesel-fuel: $43.124 \mathrm{GJ} / \mathrm{t}$; LPG: $38.978 \mathrm{GJ} / \mathrm{t}$; fuel-oil: $50.2 \mathrm{GJ} / \mathrm{t}$; And the $Y Q_{i}$ for the amount of fossil fuel used in producing heat and electricity are heat: $29.344 \mathrm{GJ} / \mathrm{t}$; and electricity: $11.84 \mathrm{GJ} / \mathrm{t}$, respectively.

\section{Results}

\subsection{Change of Rural Livelihood in the Four Water Source Areas}

The evolution characteristics of five types of livelihood capitals and the overall livelihood index for rural households in four study areas are presented in Figure 3. During a study period of 15 years, the general trend of the overall rural household livelihoods can be described as fluctuation accompanied with improvement. Taking the year 2000 as the base period, growth rates of the overall livelihood index in SY and NY were 13.0\% and 58.2\%, respectively. On the East Line, livelihood levels for TA and JN were improved by $20.4 \%$ and $43.8 \%$. Within the entire period, the average increase per year of the overall livelihood index in four regions were $0.8 \%(\mathrm{SY}), 3.1 \%(\mathrm{NY}), 1.2 \%(\mathrm{TA})$, and $2.5 \%(\mathrm{JN})$ separately.

In terms of each type of capital, except that social capital showed a downward trend, the other types of capital (natural, physical, financial, and human) either rose or remained stable (Figure 3). 
For example, according to the initial statistic-data on the variables for TA, only the NVSS was significantly cut down to 33 in 2014 from 51 in 2000, decreasing by about 35.3\%. Among all types of capitals, the most obvious variation in these four case areas were natural capitals. In comparison with that in 2000, natural capitals occupied by rural households in all four areas featured a sharp positive increase. Among these four areas, natural capitals of SY and NY increased by $72.5 \%$ and $98.8 \%$; while at the East Line, those of TA and JN substantially increased by $69.3 \%$ and $120.3 \%$. These increases for natural capitals could be attributed to the ongoing improvement on the size of farmland and, to the flow control for the industrial wastewater discharge in rural areas. Take SY as an example, the available area of agriculture land in $2014\left(2.2 \times 10^{5}\right.$ ha) was almost twice that in $2000\left(1.3 \times 10^{5} \mathrm{ha}\right)$. Also, the wastewater discharge that was adverse to protect rural ecosystem, had been reduced by $33.2 \%$ within these 15 years (from 3159.9 tons in 2000 to only 2112.1 tons in 2014). The precipitation which reflects the local climate condition presented an irregular variation trend in each area. For example, in NY the heaviest rainfall $(1031.6 \mathrm{~mm}$ ) for TA occurred in 2003, which was $28.8 \mathrm{~mm}$ and $494.2 \mathrm{~mm}$ more than that in 2011 and 2014 respectively, with significant difference. In contrast to natural capitals, the physical capitals of rural households in these four areas remained stable over the 15 years, with all changes being $<0.3 \%$ (SY: $-0.2 \%, \mathrm{NY}: 0.1 \%$, TA: $0.2 \%$ and JN: $0.3 \%$ ). These situations might be further confirmed through the slight promotion of agro-production condition (i.e., the TPAM), and of rural infrastructure (i.e., the LR). For instance, the TPAM and LR for JN, was only increased from $4.9 \times 10^{6} \mathrm{kWh}$ and $4951.1 \mathrm{~km}$ in 2000 respectively, to $5.3 \times 10^{6} \mathrm{kWh}$ and $5410.3 \mathrm{~km}$ in 2014 . For the financial capitals among the four areas, except that NY showed a reduction trend (decreased by $2.1 \%$ ), these capitals for the other three areas were increased with a range of $16.9 \%$ (SY), 35.2\% (TA), and $66.7 \%(\mathrm{JN})$, respectively. The human capitals for all study areas had a similar increase trend with the natural capitals as a whole.

The detection of significant change points indicated that total livelihood indices of SY and NY both occurred in 2006 (Figure 3a,b). Before 2006, the annual average growth rate of rural household livelihood was $1.1 \%$; however, after 2006, it turned into $0.6 \%$. Regarding NY, the variation amplitude on the rural household livelihood was $2.3 \%$ before 2006; after that, it turned into a faster positive evolution (3.9\%). On the East Line, the change point for TA was in 2004, and for JN was 2007. Before and after the transition years, the average year-by-year change rates of rural household livelihood of TA and JN presented a slower evolution tendency (TA: from $1.3 \%$ to $1.1 \%$, JN: from $3.3 \%$ to $0.9 \%$ ). In terms of each type of capital, change points for natural and physical capitals in JN appeared at 2007 and 2005 respectively, while, in 2006, it was for financial, human, and social capitals. Despite such minor differences in the year of transition, the overall livelihood transition year of the JN rural household coincided with the year of natural capitals. This is a case for the other three study areas. This phenomenon indicates that natural capitals have an important and fundamental influence on the livelihood of rural households [20]. 


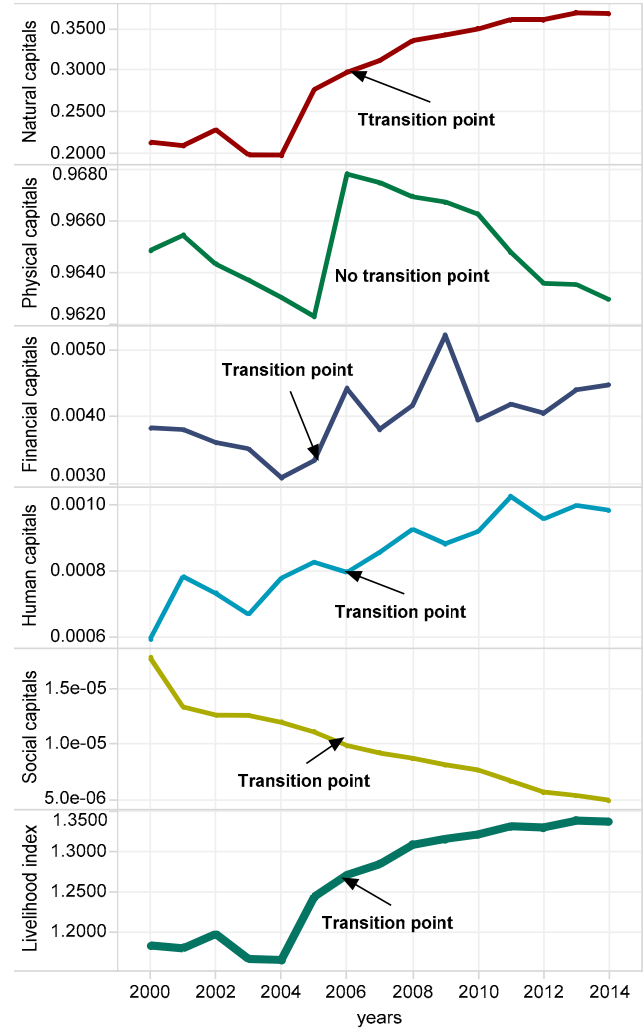

(a)

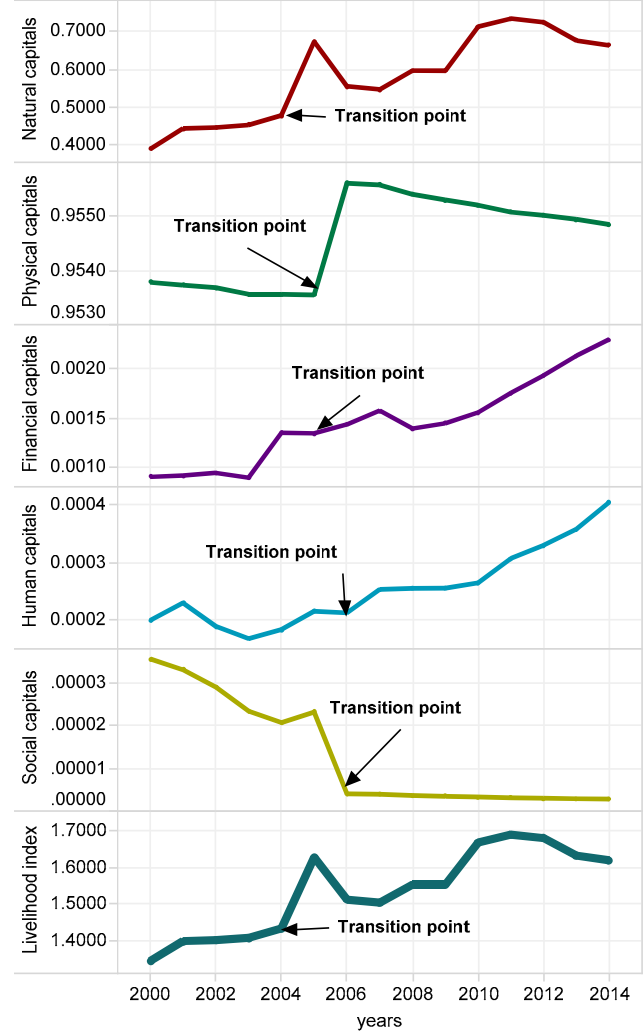

(c)

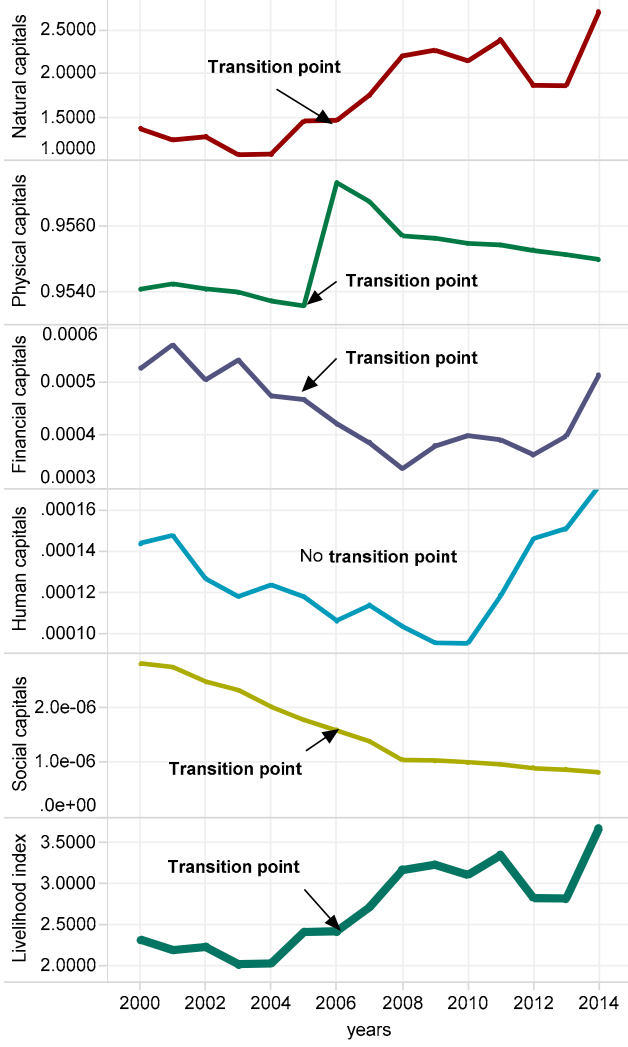

(b)

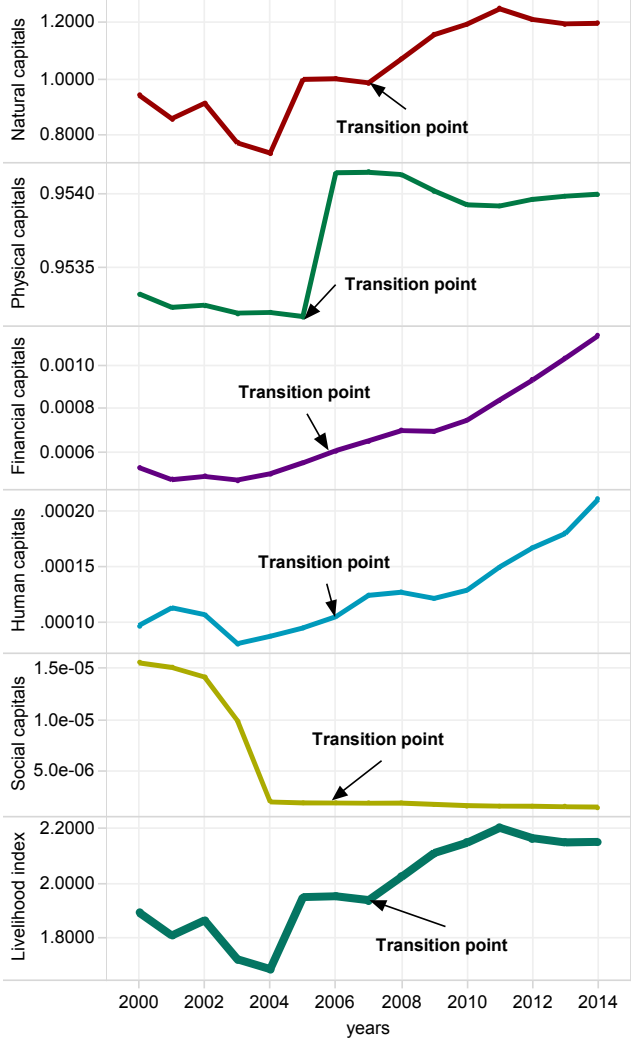

(d)

Figure 3. Change and transition points of rural livelihood in four water source areas: (a) SY; (b) NY; (c) TA; (d) JN from 2000 to 2014. 


\subsection{Change of Ecological Footprints (EF) of Rural Households}

EFs in four water source areas took on a holistic increasing trend (Figure 4). The corresponding average growth rates of SY, NY, TA, and JN were $7.6 \%, 3.4 \%, 8.8 \%$, and $4.2 \%$, respectively. In recent years, total EF of SY showed a more feverish growth rate (2013: 2.3 gha, 2014: 3.1 gha). As far as the items consisting of an EF account, productive land area (SY) required by the original material consumption of biological resources evolved into 0.6 gha per capita in 2014 from 0.5 gha per capita in 2000 , with an annual growth of $4.3 \%$. However, its proportion in the total EF declined from $47.2 \%$ at the very beginning to $29.8 \%$; that is, a mean decrease of $3.0 \%$ for those 15 years. Productive land area converted from fossil fuels and energy consumption of SY increased from 0.6 gha per capita in 2000 to 2.2 gha in 2014; the corresponding mean growth rate was as high as $9.6 \%$. The proportion of fossil fuel and energy consumption in the total EF was elevated to $70.2 \%$ by 2014 from the original $52.8 \%$. It can be clearly seen that, from 2000 to 2014, SY biological productive land area formed by biological resources, fossil fuels, and energy consumption went through a very prominent process of mutual conversion so that it gradually evolved into a total EF pattern dominated by the latter. The total EF of NY began to slightly fall after 2010 and, since then, stayed in a more stable state (Figure $4 \mathrm{~b}$ ). This was caused by the insignificant change (the average growth rate was merely $1.6 \%$ from 2010 to 2014) of productive land area led by biological resource consumption.

For TA located on the East Line Project, total EF maintained a trend of continuous increasing. EF formed by biological resources and fossil fuels and energy consumptions were 1.1 gha and 0.1 gha per capita in 2000, which turned into 1.0 gha and 3.3 gha in 2014. Their average rates of change were $-0.3 \%$ and $28.9 \%$ per year, respectively. Their proportions in the total EF were converted into $23.9 \%$ and $76.1 \%$ from the original $87.8 \%$ and $12.2 \%$; the corresponding average rates of changes were $-8.3 \%$ and $13.0 \%$. It can be also pointed out that, similar to SY in the Middle Line Project, the items consisting of EF in TA had changed substantially during those 15 years. The footprint formed by fossil fuels and energy consumption gradually became the dominant force in the total EF. In JN, Figure $4 \mathrm{~d}$ shows a trend of undulating decline since 2010 for total EF. This phenomenon was inseparable from the change of the proportion of fossil fuels and energy consumption, which was translated into $59.0 \%$ in 2014 from $62.6 \%$ in 2010. The ratios for the two consumption accounts in the total EF were translated into $41.0 \%$ and $59.0 \%$ in 2014 , while in 2000 , they were $33.4 \%$ and $66.6 \%$. The EF formed by biological resource demands in JN maintained a changing state of minor increases within the 15 years. 
(a)

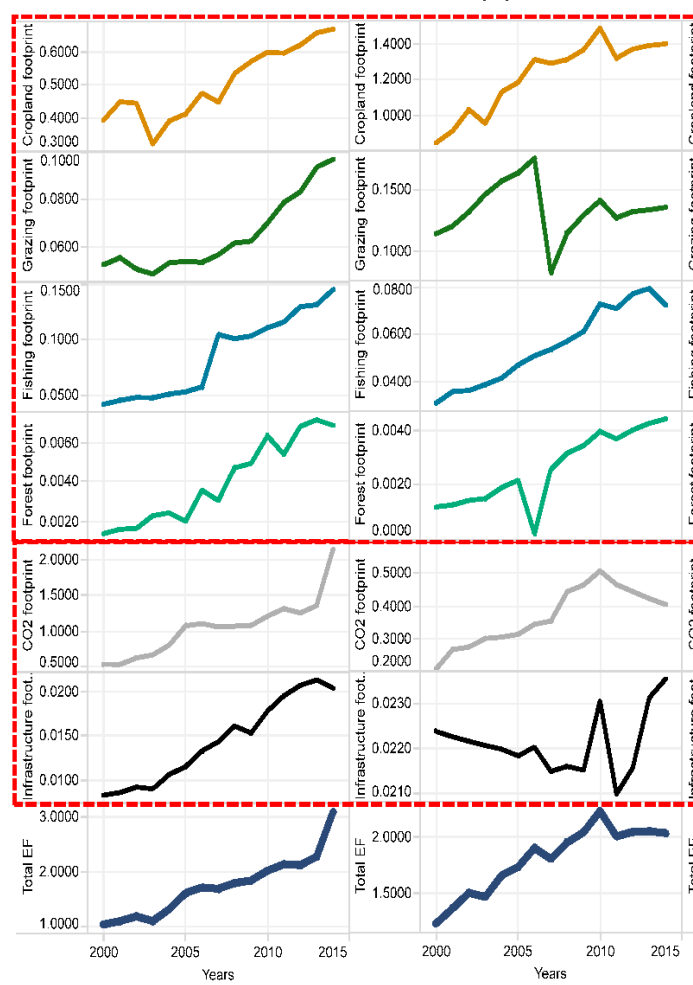

(c)

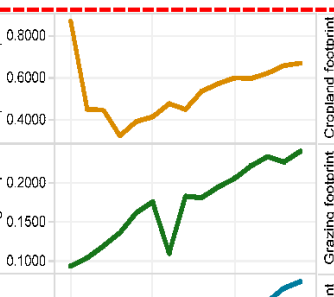

(d)

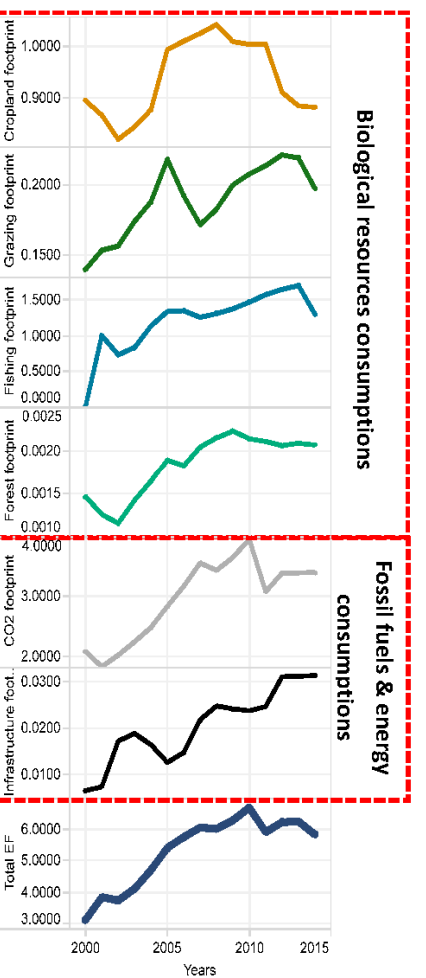

Figure 4. Change of ecological footprints of rural households in four water source areas: (a) SY; (b) NY;

(c) TA; and (d) JN from 2000 to 2014.

\subsection{Relationship between Rural Household Livelihood and Ecological Footprint in These Four Water Source} Areas

The relationship between LI and EF in each study area is shown in Figure 5. The correlation coefficients were 0.77 (SY), $0.61(\mathrm{NY}), 0.81(\mathrm{TA})$, and $0.90(\mathrm{JN})$, respectively, at a 95\% confidence interval. When regional EF increased per unit, the corresponding rural household livelihood indexes in these four areas increased by the unit of 0.11 (SY), 1.35 (NY), 0.10 (TA), and 0.12 (JN) units, respectively. This finding clearly indicates that the improvement of rural household livelihoods in all four areas required certain $\mathrm{EF}$ increments $[10,54,60]$. In addition, it was found from a perspective of elasticity that if a regional EF was improved by $1 \%$, the rural household livelihood level in these four areas will rise by $5.8 \%(\mathrm{SY}), 1.1 \%(\mathrm{NY}), 0.9 \%(\mathrm{TA})$, and $0.5 \%(\mathrm{JN})$, correspondingly.

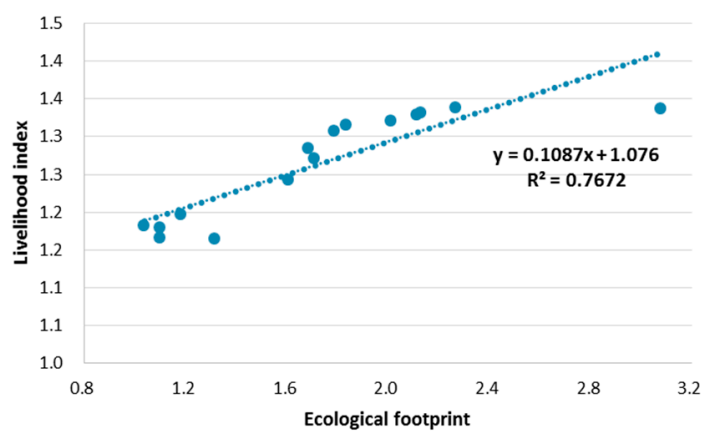

(a)

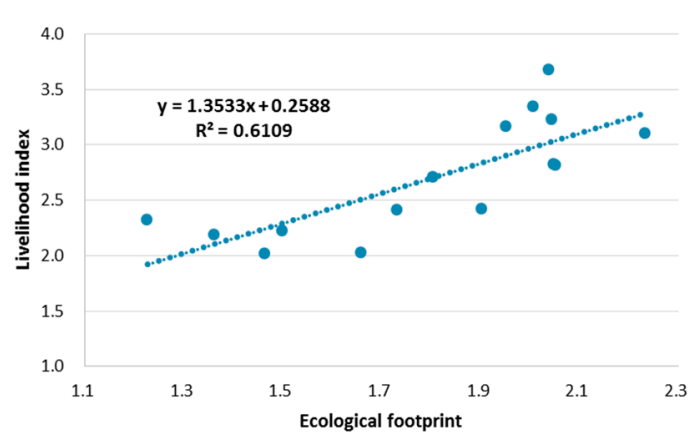

(b)

Figure 5. Cont. 


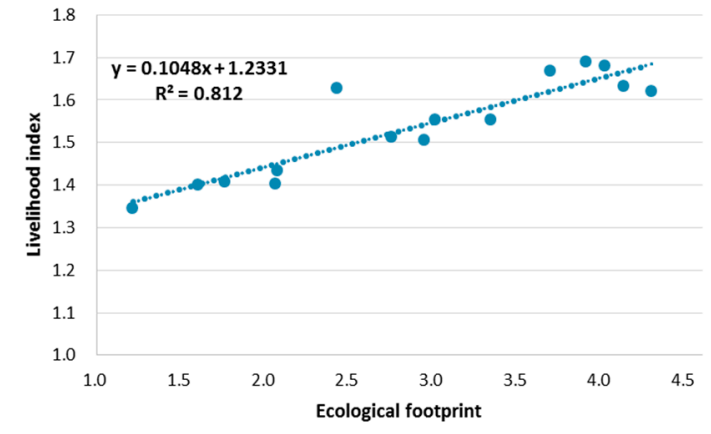

(c)

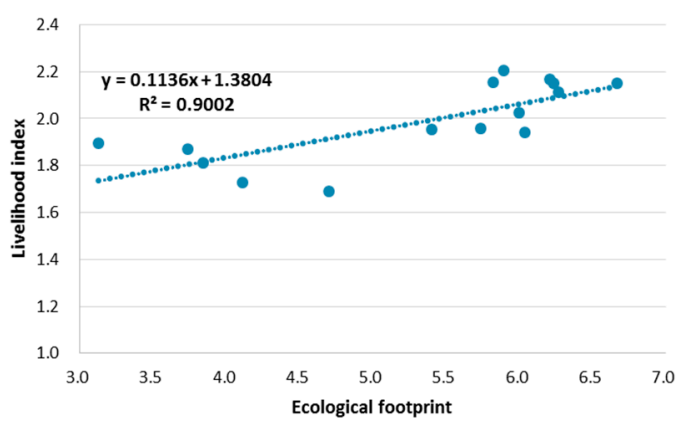

(d)

\begin{tabular}{|c|c|c|c|c|c|c|}
\multirow{2}{*}{ Region } & \multirow{2}{*}{$\mathbf{R}^{2}$-Value } & Slope & Intercept & \multirow{2}{*}{ F-Value } & \multicolumn{2}{|c|}{ T-Value } \\
\cline { 5 - 7 } & & & & & Slope & Intercept \\
\hline (a) SY & 0.7672 & 0.1087 & 1.0760 & $42.840^{* *}$ & $35.735^{* *}$ & $6.545^{* *}$ \\
(b) NY & 0.6109 & 1.3533 & 0.2588 & $20.409^{* *}$ & $2.118^{* *}$ & $4.518^{* *}$ \\
(c) TA & 0.8120 & 0.1048 & 1.2331 & $56.158^{* *}$ & $7.494^{* *}$ & $28.954^{* *}$ \\
(d) JN & 0.9002 & 0.1136 & 1.3804 & $17.514^{* *}$ & $4.185^{* *}$ & $9.360^{* *}$ \\
\hline
\end{tabular}

Figure 5. Relationship between rural household livelihood and ecological footprint in four water source areas: (a) SY; (b) NY; (c) TA; and (d) JN.

\subsection{Comparisons among These Four Water Source Areas}

Rural household livelihood in these four water source areas exhibited a general trend of positive development. In 2014, the integrated livelihood index for NY was the highest (3.7), followed by JN (2.2) from the East Line. The development level of such a rural household livelihood in SY (1.3) was lower than that of TA (1.7). Before each transition point, the annual average improvement rate of rural household livelihood for JN was the highest (3.1\%), which was followed by NY (2.4\%), TA $(1.3 \%)$, and SY (1.1\%). After those points, the level of rural household livelihood for NY (3.9\%) still showed a positive evolution; the average growth rate with years of TA $(1.1 \%)$ ranked second, while JN $(0.9 \%)$ and SY $(0.6 \%)$ were located at the last two positions, respectively (Figure 6a). Furthermore, there were obvious differences existing in the development levels of rural household livelihood at the transition points.

As shown in Figure $6 \mathrm{~b}$, the intensity of human activities exerted on EF was the strongest for JN (5.8 gha) in 2014, which was 1.5 gha, 2.7 gha, and 3.8 gha more than TA, SY, and NY, respectively. However, back in 2000, there were no significant differences on the ecological impact levels among SY (1.0 gha), NY (1.2 gha), and TA (1.3 gha). The EF in 2000 for each of these three regions was almost a third of JN (3.2 gha) as a whole. The EF accounts for SY, TA, and JN were gradually turned into a total EF pattern dominated by fossil fuels and energy consumption. On the contrary, a pattern with biological resource demands playing a dominant role was always maintained for NY.

By further comparative observations from Figure $6 c$, the rural livelihood increments incurred by improvement of regional $\mathrm{EF}$ had a substantial difference among these four water source areas. For each unit of EF increase, the increment of LI at NY (1.35 units) is the most prominent, next for JN (0.12 unit), then for SY (0.11) and TA (0.10), respectively. In other words, NY has the lowest ecological cost to improve the rural household livelihood. Moreover, compared with JN (elastic coefficient: 0.5), SY (elastic coefficient: 5.8) manifested as the most significant response of rural livelihood to regional EF variations. This means that SY has the largest stress on improving rural livelihood when regional $\mathrm{EF}$ is decreased without any external interventions. 


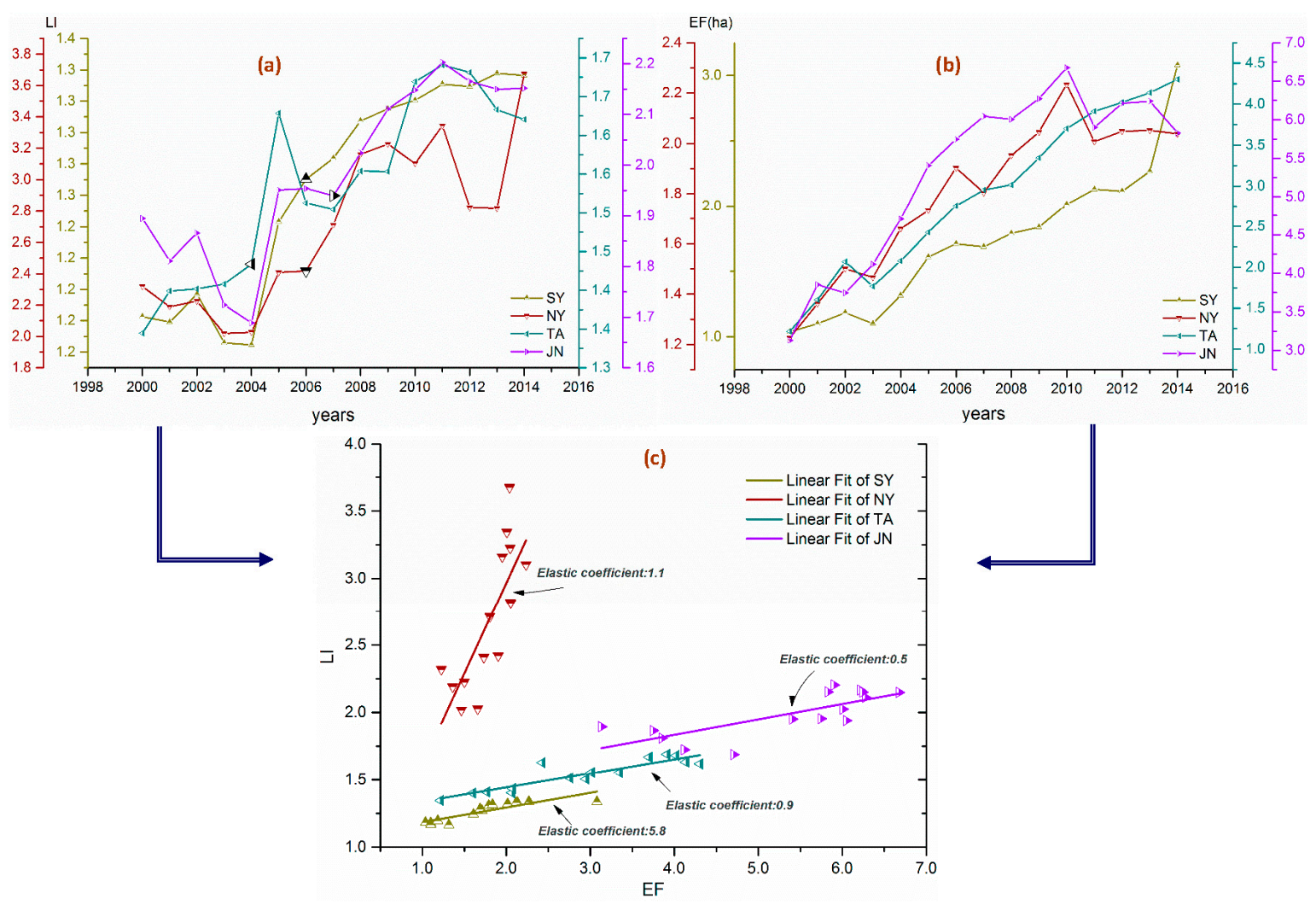

Figure 6. Comparisons among four water source areas: (a) the distinctions on the change and transition points of the livelihood index of four water source areas; (b) the distinctions on the change of total ecological footprints of four water source areas; and (c) the differences in correlation strengths and elastic coefficients between the rural livelihood index and the total per capita ecological footprint of four water source areas.

\section{Discussions and Conclusions}

This paper developed an understanding of the dynamic interactions between rural livelihood development and the ecological footprint in four water source areas of SNWDP: SY, NY, TA, and JN. 15 years of evolution of rural household livelihood and the intensity of regional resources consumed in these four study areas was investigated through using the tools of the livelihood index and ecological footprint accounting. The response of the regional eco-footprint to the change in rural livelihood was also discussed. Major research findings and their implications for practices and future research are discussed below.

The evolution trend of natural capital of rural households determines the overall changing track of rural livelihood (Figure 3). The existing rural households whose livelihood strategies and activities that depend on natural capitals will be limited by a series of ecological conservation policies for water quality improvement of the SNWDP. For example, local government plans required that all aquaculture facilities should be dismantled from Danjiangkou Reservoir [58,59]. This policy could lead to large-scale livelihood downturn for those fishermen and communities who depend on the aquaculture earnings [74-77]. To maintain and improve livelihood outcomes, new wage income opportunities should be provided in proportion to the lost natural capital income, or a substitute livelihood strategy of non-agriculturization should be established [25]. Ellis argued that the promotion of human and social capital was very significant to the successful implementation of a non-agriculture livelihood strategy for rural households [10]. Unfortunately, social capitals for rural households in the four selected areas all have a decreasing trend (Figure 3). Thus, improvement of occupational skills and abilities in public services should be adopted more intensely to realize social capital appreciation. 
In addition, due to large numbers of relocation and resettlement incurred by the SNWDP for the past few years, the social network in rural areas that was originally stable has been isolated artificially. The collapse of the social support system has a rather long-term negative impact on social capitals of rural households [78]. The decrease of the NVSS and NCSF in rural areas could be one of the consequences of these negative impacts. It is urgent to recover the social service system, especially in those newly resettled areas to improve the capacity of grassroots governance.

Rural household livelihoods in three of these regions lack strength in growth after the transition (Figures 3 and 6a). This is because the natural capital, a key stock that produces a flow of services and incomes, kept a lower growth rate after the transition year for each of these three areas. Some evidence further shows that this situation is also caused by a mass of natural capital over-exploitation, such as reclamation of wetlands and forests, which leads to rural ecosystem deterioration [56,79]. Although expansion of the size of farmland could facilitate the diversity of using natural capitals in these three areas, it may have damaged soil fertility through employing many agricultural chemicals for yield promotion. Therefore, new growth impetus for rural livelihoods which contribute to long-term sustainable development of farming, should be introduced. In addition, substantial differences exist in the rural household livelihood levels in these four water source areas (Figures 3 and 6a). These livelihood differences come from historical contexts, but they should be eliminated to narrow the disparity of development between the Middle and East Line for the SNWDP.

It is found that EF per capita in each area keeps expanding and gradually turns into a prominent trend led by fossil fuels and energy consumption (Figure 4). The rural household livelihood grows with the expansion of regional EF in all water source areas (Figure 5). This finding conforms to the theory of livelihood thinking $[10,15,61]$. A great deal of evidence shows that when ecological resources in a water source area are excessively used by humans, adverse impacts can be generated for both the security and the sustainable supply of clean water $[8,80]$. Unfortunately, EF, itself, has no ability in assessing these specific eco-environmental impacts, such as those arising from high-intensity use of natural resources. Life Cycle Assessment (LCA) has been highlighted as a means for improving EF methods to calculate impacts accounted for within the EF [46,81-83]. Using the LCA tool, the quantified impacts for the overall life cycle of regional resource consumption could be derived for policy design on balancing livelihood sustainability and eco-environmental security.

Beyond that, some policy interventions should be considered from both directions of improving rural household livelihoods and controlling the expansion of regional EF in the "post South-to-North Water Diversion era" (Figure 7). They are: population transfer and relocation, industrial restructuring and upgrading, rural infrastructure and communities' reconstruction, and ecological compensation. Resettlement of rural households within a conservation area should be carried out based on the household's willingness and equality between adjacent regions. The lost physical and financial capitals of rural households due to resettlement should be compensated in line with their market values. At the same time, in conformity with holistic resource endowment, diversified natural capitals should be also configured to those who are resettled as agricultural population [6]. This will directly improve the livelihood of affected households. Industrial restructuring and upgrading is a basic guarantee to rural household livelihood transformation toward ecological sustainability. On one hand, reliable and high value-added industries are able to absorb surplus rural labor forces and provide stable and diversified financial capital sources to rural households. On the other hand, elimination of high-pollution outdated industries, reduction in industrial waste discharges per capita, as well as energy consumption per unit of GDP, will help relieve regional environmental deterioration and resource supply pressures, so as to further cut down the ecological footprint effectively. Advancing the development of ecological tourism is one example $[84,85]$. Rural infrastructure and community reconstruction is a critical policy to deal with reduced social capital and human capital. Selectable tools could include an increase in educational and cultural facility supplies, the provision of diversified occupational training, new non-agricultural employment opportunities, and empowerment for peasants in terms of renewing their livelihood strategies and participating in grassroots governance [86]. Furthermore, cross-regional 
eco-compensation policies should be established. The fundamental goal of such policies is to give comprehensive compensation from the region that benefits from the SNWDP to rural households in water source areas whose livelihood growth is restricted due to efforts taken to ensure the water quality of the SNWDP [87]. The forms of eco-compensation can be divided into livelihood improvement programs, monetary subsidies, and intergovernmental fiscal transfers. These four policy instruments, supplementing each other, will jointly limit the rapid increase in EF and promote rural household livelihoods (Figure 7).

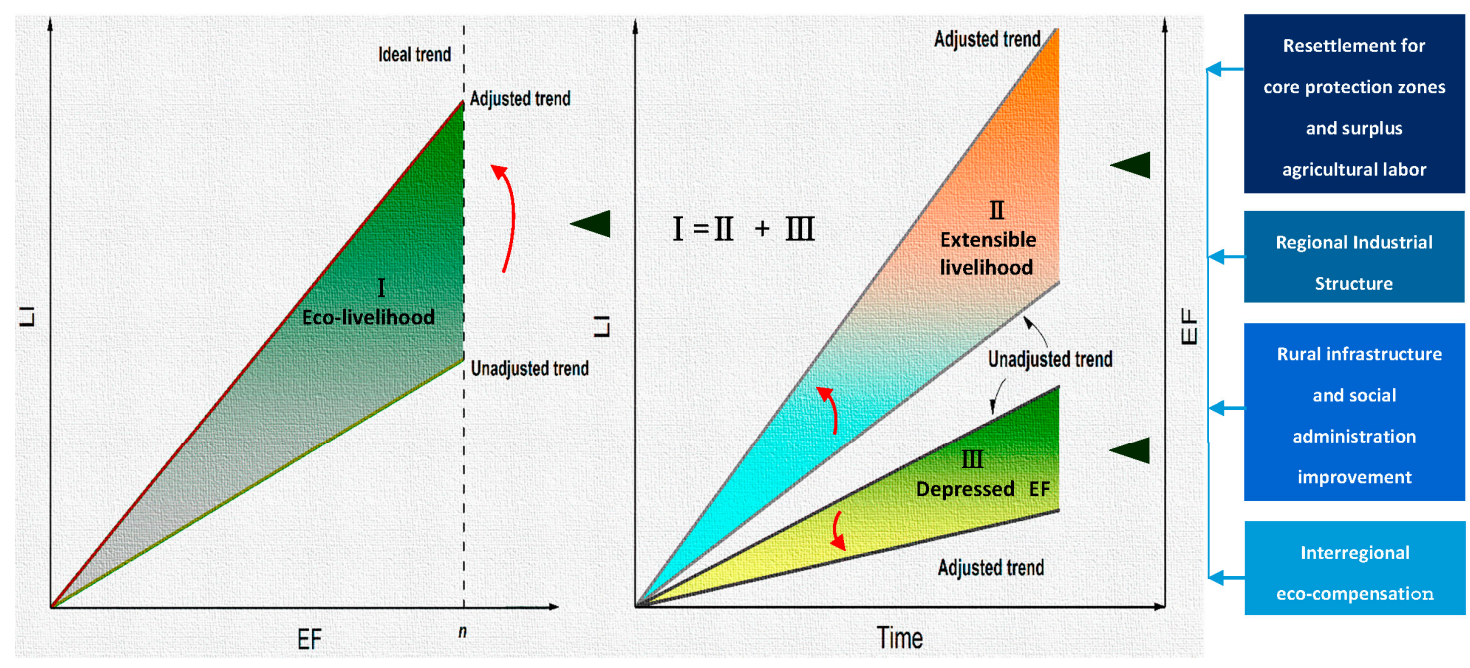

Figure 7. Theoretical path and policy measures.

In summary, this paper provided an empirical study of understanding the dynamic interaction between rural livelihoods and ecological footprints using long series quantitative data at the regional level. The key findings from this study are vital for policy-making on water quality improvement in four water source areas of SNWDP and other similar regions. However, some limitations in our study need to be acknowledged. The livelihood variable selected in this study is limited to the accessibility of data, so some new emerging livelihood capitals, such as Internet technologies, are excluded. Then, the quantifications for the monetary values of some livelihood-capitals might be insufficient because of the complexity in defining the explicit economic attributes of environmental or social factors. Finally, more comprehensive environmental assessments, such as LCA, should be integrated with EF to track the dynamic evolution of the livelihood-ecology nexus.

Acknowledgments: This research was funded by the National Social Science Foundation of China (Project Grant No. 13 \& ZD172; 16CSH019). This work was also supported by the Australian Research Council (Project No. FT130100274). The authors appreciate the Chinese Scholarship Council for its support, and would like to thank the anonymous reviewers for their insightful and helpful comments on the manuscript.

Author Contributions: Chen Wang, Guoqing Shi, and Yongping Wei conceived and designed the experiments; Chen Wang and Yongping Wei performed the experiments; Chen Wang, Yongping Wei, and Hang Zheng analyzed the data; Guoqing Shi, Andrew, and Yan Zhao contributed reagents/materials/analysis tools; Chen Wang wrote the paper.

Conflicts of Interest: The authors declare no conflict of interest.

\section{References}

1. World Bank. World Development Indicators; World Bank Publications: Washington, DC, USA, 2016.

2. Gentle, P.; Maraseni, T.N. Climate change, poverty and livelihoods: Adaptation practices by rural mountain communities in Nepal. Environ. Sci. Policy 2012, 21, 24-34. 
3. Tanner, T.; Lewis, D.; Wrathall, D.; Bronen, R.; Cradock-Henry, N.; Huq, S.; Lawless, C.; Nawrotzki, R.; Prasad, V.; Rahman, A.; et al. Livelihood resilience in the face of climate change. Nat. Clim. Chang. 2015, 5, 23-26. [CrossRef]

4. Ferrol-Schulte, D.; Wolff, M.; Ferse, S.; Glaser, M. Sustainable Livelihoods Approach in tropical coastal and marine social-ecological systems: A review. Mar. Policy 2013, 42, 253-258. [CrossRef]

5. Jones, P.G.; Thornton, P.K. Croppers to livestock keepers: Livelihood transitions to 2050 in Africa due to climate change. Environ. Sci. Policy 2009, 12, 427-437. [CrossRef]

6. Cernea, M.M.; Schmidt-Soltau, K. Poverty Risks and National Parks: Policy Issues in Conservation and Resettlement. World Dev. 2006, 34, 1808-1830. [CrossRef]

7. Warner, K. Global environmental change and migration: Governance challenges. Glob. Environ. Chang. 2010, 20, 402-413. [CrossRef]

8. United Nations Educational, Scientific and Cultural Organization. Water for a Sustainable World; United Nations Educational, Scientific and Cultural Organization: Parsi, France, 2015.

9. Ma, Z.; Kang, S.; Zhang, L.; Tong, L.; Su, X. Analysis of impacts of climate variability and human activity on streamflow for a river basin in arid region of northwest China. J. Hydrol. 2008, 352, 239-249. [CrossRef]

10. Ellis, F. Rural Livelihoods and Diversity in Developing Countries; Oxford University Press: Oxford, UK, 2000.

11. Nkemnyi, M.F.; de Haas, A.; Etiendem, N.D.; Ndobegang, F. Making hard choices: Balancing indigenous communities livelihood and Cross River gorilla conservation in the Lebialem-Mone Forest landscape, Cameroon. Environ. Dev. Sustain. 2013, 15, 841-857. [CrossRef]

12. Singh, N.; Gilman, J. Making Livelihoods Sustainability. Int. Soc. Sci. J. 2000, 17, 123-129.

13. International Organization for Migration. Outlook on Migration Environment and Climate Change; International Organization for Migration: Geneva, Switzerland, 2015; pp. 21-27.

14. Gallardo, M.C. Socio-Ecological Inequality and Water Crisis: Views of Indigenous Communities in the Alto Loa Area. Environ. Justice 2016, 9, 9-14. [CrossRef]

15. Chambers, R.; Conway, G. Sustainable Rural Livelihoods: Practical Concepts for the 21st Century; Institute of Development Studies: Falmer, UK, 1992.

16. Costanza, R.; de Groot, R.; Sutton, P.; van der Ploeg, S.; Anderson, S.J.; Kubiszewski, I.; Farber, S.; Turner, R.K. Changes in the global value of ecosystem services. Glob. Environ. Chang. 2014, 26, 152-158. [CrossRef]

17. Leach, M.; Mearns, R.; Scoones, I. Environmental entitlements: Dynamics and institutions in community-based natural resource management. World Dev. 1999, 27, 225-247. [CrossRef]

18. Daily, G. Nature's Services: Societal Dependence on Natural Ecosystems; Island Press: Washington, DC, USA, 1997.

19. Biggs, E.M.; Bruce, E.; Boruff, B.; Duncan, J.M.A.; Horsley, J.; Pauli, N.; McNeill, K.; Neef, A.; Van Ogtrop, F.; Curnow, J.; et al. Sustainable development and the water-energy-food nexus: A perspective on livelihoods. Environ. Sci. Policy 2015, 54, 389-397. [CrossRef]

20. Scoones, I. Livelihoods perspectives and rural development. J. Peasant Stud. 2009, 36, 171-196. [CrossRef]

21. Angelsen, A.; Jagger, P.; Babigumira, R.; Belcher, B.; Hogarth, N.J.; Bauch, S.; Börner, J.; Smith-Hall, C.; Wunder, S. Environmental income and rural livelihoods: A global-comparative analysis. World Dev. 2014, 64, S12-S28. [CrossRef]

22. Sreeja, K.G.; Madhusoodhanan, C.G.; Eldho, T.I. Transforming river basins: Post-livelihood transition agricultural landscapes and implications for natural resource governance. J. Environ. Manag. 2015, 159, 254-263. [CrossRef] [PubMed]

23. Bebbington, A. Capitals and capabilities: A framework for analyzing peasant viability, rural livelihoods and poverty. World Dev. 1999, 27, 2021-2044. [CrossRef]

24. Hussein, K. Livelihoods Approaches Compared; Department for International Development: London, UK, 2002.

25. Kemkes, R.J. The role of natural capital in sustaining livelihoods in remote mountainous regions: The case of Upper Svaneti, Republic of Georgia. Ecol. Econ. 2015, 117, 22-31. [CrossRef]

26. Maas, L.T.; Sirojuzilam; Erlina; Badaruddin. The Effect of Social Capital on Governance and Sustainable Livelihood of Coastal City Community Medan. Procedia Soc. Behav. Sci. 2015, 211, 718-722. [CrossRef]

27. Bhandari, P.B. Rural livelihood change? Household capital, community resources and livelihood transition. J. Rural Stud. 2013, 32, 126-136. [CrossRef] [PubMed]

28. Morse, S.; Acholo, M.; McNamara, N. Sustainable Livelihood Approach: A Critical Analysis of Theory and Practice; University of Reading: Reading, UK, 2009. 
29. Carr, E.R. Livelihoods as Intimate Government: Reframing the logic of livelihoods for development. Third World Q. 2013, 34, 77-108. [CrossRef]

30. Sayatham, M.; Suhardiman, D. Hydropower resettlement and livelihood adaptation: The Nam Mang 3 project in Laos. Water Resour. Rural Dev. 2015, 5, 17-30. [CrossRef]

31. Thapa Karki, S. Do protected areas and conservation incentives contribute to sustainable livelihoods? A case study of Bardia National Park, Nepal. J. Environ. Manag. 2013, 128, 988-999. [CrossRef] [PubMed]

32. Qing, T. Research Progress and Future Key Trends of Sustainable Livelihoods. Adv. Earth Sci. 2015, 30, 823-833.

33. Turner, M.D.; Ayantunde, A.A.; Patterson, K.P.; Patterson, E.D., III. Livelihood transitions and the changing nature of farmer-herder conflict in Sahelian West Africa. J. Dev. Stud. 2011, 47, 183-206. [CrossRef] [PubMed]

34. Bohle, H.-G. Sustainable livelihood security. Evolution and application. In Facing Global Environmental Change; Springer: New York, NY, USA, 2009; pp. 521-528.

35. Goulden, M.C.; Adger, W.N.; Allison, E.H.; Conway, D. Limits to resilience from livelihood diversification and social capital in lake social-ecological systems. Ann. Assoc. Am. Geogr. 2013, 103, 906-924. [CrossRef]

36. McLean, J.E. Beyond the pentagon prison of sustainable livelihood approaches and towards livelihood trajectories approaches. Asia Pac. Viewp. 2015, 56, 380-391. [CrossRef]

37. Reed, M.S.; Podesta, G.; Fazey, I.; Geeson, N.; Hessel, R.; Hubacek, K.; Letson, D.; Nainggolan, D.; Prell, C.; Rickenbach, M.G.; et al. Combining analytical frameworks to assess livelihood vulnerability to climate change and analyse adaptation options. Ecol Econ. 2013, 94, 66-77. [CrossRef] [PubMed]

38. Singh, P.K.; Hiremath, B.N. Sustainable livelihood security index in a developing country: A tool for development planning. Ecol. Indic. 2010, 10, 442-451. [CrossRef]

39. Hahn, M.B.; Riederer, A.M.; Foster, S.O. The Livelihood Vulnerability Index: A pragmatic approach to assessing risks from climate variability and change-A case study in Mozambique. Glob. Environ. Chang. 2009, 19, 74-88. [CrossRef]

40. Donohue, C.; Biggs, E. Monitoring socio-environmental change for sustainable development: Developing a Multidimensional Livelihoods Index (MLI). Appl. Geogr. 2015, 62, 391-403. [CrossRef]

41. Shah, K.U.; Dulal, H.B.; Johnson, C.; Baptiste, A. Understanding livelihood vulnerability to climate change: Applying the livelihood vulnerability index in Trinidad and Tobago. Geoforum 2013, 47, 125-137. [CrossRef]

42. Etwire, P.M.; Al-Hassan, R.M.; Kuwornu, J.K.M.; Osei-Owusu, Y. Application of livelihood vulnerability index in assessing vulnerability to climate change and variability in Northern Ghana. J. Environ. Earth Sci. 2013, 3, 157-170.

43. Wackernagel, M.; Rees, W. Our Ecological Footprint: Reducing Human Impact on the Earth; New Society Publishers: Gabriola Island, BC, Canada, 1998.

44. Kick, E.L.; McKinney, L.A. Global Context, National Interdependencies, and the Ecological Footprint: A Structural Equation Analysis. Sociol. Perspect. 2014, 57. [CrossRef]

45. Van den Bergh, J.C.J.M.; Verbruggen, H. Spatial sustainability, trade and indicators: An evaluation of the 'ecological footprint'. Ecol. Econ. 1999, 29, 61-72. [CrossRef]

46. Čuček, L.; Klemeš, J.J.; Kravanja, Z. A review of footprint analysis tools for monitoring impacts on sustainability. J. Clean. Prod. 2012, 34, 9-20. [CrossRef]

47. Li, J.; Liu, Z.; He, C.; Tu, W.; Sun, Z. Are the drylands in northern China sustainable? A perspective from ecological footprint dynamics from 1990 to 2010. Sci. Total Environ. 2016, 553, 223-231. [CrossRef] [PubMed]

48. Toth, G.; Szigeti, C. The historical ecological footprint: From over-population to over-consumption. Ecol. Indic. 2016, 60, 283-291. [CrossRef]

49. Aşıc1, A.A.; Acar, S. Does income growth relocate ecological footprint? Ecol. Indic. 2016, 61, 707-714. [CrossRef]

50. Cobbinah, P.B.; Black, R.; Thwaites, R. Biodiversity conservation and livelihoods in rural Ghana: Impacts and coping strategies. Environ. Dev. 2015, 15, 79-93. [CrossRef]

51. Gajurel, J.P.; Shrestha, K.K.; Werth, S.; Scheidegger, C. Taxus wallichiana (Himalayan Yew) for the Livelihood of Local People in Some Protected Areas of Nepal. J. Nat. Hist. Mus. 2015, 28, 1-8.

52. Rantala, S.; Bullock, R.; Mbegu, M.A.; German, L.A. Community-Based Forest Management: What scope for conservation and livelihood co-benefits? Experience from the East Usambara Mountains, Tanzania. J. Sustain. For. 2012, 31, 777-797. [CrossRef] 
53. Bennett, N.J.; Dearden, P. Why local people do not support conservation: Community perceptions of marine protected area livelihood impacts, governance and management in Thailand. Mar. Policy 2014, 44, 107-116. [CrossRef]

54. Hao, H.; Zhang, J.; Li, X.; Zhang, H.; Zhang, Q. Impact of livelihood diversification of rural households on their ecological footprint in agro-pastoral areas of northern China. J. Arid Land 2015, 7, 653-664. [CrossRef]

55. Pohlner, H. Institutional change and the political economy of water megaprojects: China's south-north water transfer. Glob. Environ. Chang. 2016, 38, 205-216. [CrossRef]

56. Li, G.; Wang, Y. An analysis on environmental protection and compensation policies of South-to-North Water Transfer Project Water Source Area. Stat. Inf. Forum 2015, 30, 92-98.

57. Wang, L.; Huang, J.; Du, Y. Eco-environmental evaluation of middle route of the South-to-North Water Transfer Project. Resour. Environ. Yangtze Basin 2011, 20, 161-166.

58. Government of Henan. The Scheme for Dividing the Drinking Water Source Conservation Area in Danjiangkou Reservoir (Henan Province) of South-to-North Water Transfer Project. Available online: http:/ / www.henan.gov.cn/zwgk/system/2015/04/29/010547386.shtml (accessed on 21 June 2015).

59. Government of Hubei. The Scheme for Dividing the Drinking Water Source Conservation Area in Danjiangkou Reservoir (Hubei Province) of South-to-North Water Transfer Project. Available online: http://gkml.hubei.gov.cn/auto5472/auto5473/201502/t20150205_616483.html (accessed on 21 June 2015).

60. Government of Shandong. The Planning for the Key Ecological Function Areas in Shandong Province. Available online: http:/ /lyc.sdein.gov.cn/swgnbhq/200912/t20091209_208968.html (accessed on 21 June 2015).

61. Mensah, E.J. The Sustainable Livelihood Framework: A Reconstruction. Dev. Rev. 2012, 1, 7-24.

62. Carney, D. Sustainable Livelihoods Approaches: Progress and Possibilities for Change; Department for International Development: London, UK, 2003.

63. Bartlett, R.; Bharati, L.; Pant, D.; Hosterman, H.; McCornick, P. Climate Change Impacts and Adaptation in Nepal; IWMI: Durham, NC, USA, 2010.

64. Sheriff, N.; Little, D.C.; Tantikamton, K. Aquaculture and the poor-Is the culture of high-value fish a viable livelihood option for the poor? Mar. Policy 2008, 32, 1094-1102. [CrossRef]

65. Government of the People's Republic of China. The 13th Five-Year Plan for Economic and Social Development of the People's Republic of China (the 13th Five-Year Plan); Government of the People's Republic of China: Beijing, China, 2016.

66. Heidecke, C. Development and Evaluation of a Regional Water Poverty Index for Benin; International Food Policy Research Institute: Washington, DC, USA, 2006.

67. Pettitt, A.N. A non-parametric approach to the change-point problem. Appl. Stat. 1979, 28, 126-135. [CrossRef]

68. Borucke, M.; Moore, D.; Cranston, G.; Gracey, K.; Iha, K.; Larson, J.; Lazarus, E.; Morales, J.C.; Wackernagel, M.; Galli, A. Accounting for demand and supply of the biosphere's regenerative capacity: The National Footprint Accounts' underlying methodology and framework. Ecol. Indic. 2013, 24, 518-533. [CrossRef]

69. Wackernagel, M.; Monfreda, C.; Schulz, N.B.; Erb, K.-H.; Haberl, H.; Krausmann, F. Calculating national and global ecological footprint time series: Resolving conceptual challenges. Land Use Policy 2004, 21, 271-278. [CrossRef]

70. Dismuke, C.; Lindrooth, R. Ordinary least squares. Methods and Designs for Outcomes Research; ASHP: Bethesda, MD, USA, 2006; p. 93.

71. Wackernagel, M.; Monfreda, C.; Moran, D.; Wermer, P.; Goldfinger, S.; Deumling, D.; Murray, M. National Footprint and Biocapacity Accounts 2005: The Underlying Calculation Method; Global Footprint Network Oakland: Oakland, CA, USA, 2005.

72. Lee, Y.-J.; Peng, L.-P. Taiwan's Ecological Footprint (1994-2011). Sustainability 2014, 6, 6170-6187. [CrossRef]

73. Huang, B.; Cui, S.; Li, Y. Ecological Footprint Evolution Characteristics and Its Influencing Factors in China from 2000 to 2010. Environ. Sci. 2016, 37, 420-426.

74. Kincaid, K.B.; Rose, G.A. Why fishers want a closed area in their fishing grounds: Exploring perceptions and attitudes to sustainable fisheries and conservation 10 years post closure in Labrador, Canada. Mar. Policy 2014, 46, 84-90. [CrossRef] 
75. Foale, S.; Manele, B. Social and political barriers to the use of marine protected areas for conservation and fishery management in Melanesia. Asia Pac. Viewp. 2004, 45, 373-386. [CrossRef]

76. Silva, P. Exploring the Linkages Between Poverty, Marine Protected Area Management, and the Use of Destructive Fishing Gear in Tanzania; World Bank Policy Research Working Paper (3831); World Bank: Washington, DC, USA, 2006.

77. Allison, E.H.; Ellis, F. The livelihoods approach and management of small-scale fisheries. Mar. Policy 2001, 25, 377-388. [CrossRef]

78. Zhao, J. Resettlement Management and Practice of the South to North Water Diversion East Project; Shandong University: Jinan, China, 2009.

79. Zhou, J. The Predicament and the Improvement of Migrant Resettlement Monitoring and Evaluation of South-to-North Water Diversion Project. Jiangsu Soc. Sci. 2011, 6, 61-65.

80. Bogardi, J.J.; Dudgeon, D.; Lawford, R.; Flinkerbusch, E.; Meyn, A.; Pahl-Wostl, C.; Vielhauer, K.; Vörösmarty, C. Water security for a planet under pressure: interconnected challenges of a changing world call for sustainable solutions. Curr. Opin. Environ. Sustain. 2012, 4, 35-43. [CrossRef]

81. Lundin, M.; Morrison, G.M. A life cycle assessment based procedure for development of environmental sustainability indicators for urban water systems. Urban Water 2002, 4, 145-152. [CrossRef]

82. Castellani, V.; Sala, S. Ecological Footprint and Life Cycle Assessment in the sustainability assessment of tourism activities. Ecol. Indic. 2012, 16, 135-147. [CrossRef]

83. Lo-Iacono-Ferreira, V.G.; Torregrosa-López, J.I.; Capuz-Rizo, S.F. Use of life cycle assessment methodology in the analysis of ecological footprint assessment results to evaluate the environmental performance of universities. J. Clean. Prod. 2016, 133, 43-53. [CrossRef]

84. Gliessman, S.R. (Ed.) Agroecology: Researching the Ecological Basis for Sustainable Agriculture, Agroecology; Springer: New York, NY, USA, 1990; pp. 3-10.

85. Garnett, T.; Appleby, M.C.; Balmford, A.; Bateman, I.J.; Benton, T.G.; Bloomer, P.; Burlingame, B.; Dawkins, M.; Dolan, L.; Fraser, D. Sustainable intensification in agriculture: Premises and policies. Science 2013, 341, $33-34$. [CrossRef] [PubMed]

86. Reid, R.S.; Nkedianye, D.; Said, M.Y.; Kaelo, D.; Neselle, M.; Makui, O.; Onetu, L.; Kiruswa, S.; Kamuaro, N.O.; Kristjanson, P. Evolution of models to support community and policy action with science: Balancing pastoral livelihoods and wildlife conservation in savannas of East Africa. Proc. Natl. Acad. Sci. USA 2016, 113, 4579-4584. [CrossRef] [PubMed]

87. Bremer, L.L.; Farley, K.A.; Lopez-Carr, D.; Romero, J. Conservation and livelihood outcomes of payment for ecosystem services in the Ecuadorian Andes: What is the potential for 'win-win'? Ecosyst. Serv. 2014, 8, 148-165. [CrossRef]

(C) 2017 by the authors. Licensee MDPI, Basel, Switzerland. This article is an open access article distributed under the terms and conditions of the Creative Commons Attribution (CC BY) license (http://creativecommons.org/licenses/by/4.0/). 